\title{
Toxoplasma gondii in milk of naturally infected dairy ewes on west mesoregion of Santa Catarina state, Brazil
}

\author{
[Toxoplasma gondii em leite de ovelhas leiteiras naturalmente infectadas na \\ mesorregião oeste de Santa Catarina, Brasil] \\ R.A. Ossani, H.A.T. Borges, A.P. Souza, A.A. Sartor, L.C. Miletti, \\ M. Federle, A.B. Moura* \\ Universidade do Estado de Santa Catarina - Centro de Ciências \\ Agroveterinárias - UDESC-CAV) - Lages, SC
}

\begin{abstract}
This study aimed to detect Toxoplasma gondii in the milk of dairy sheep in the Western mesorregion of state of Santa Catarina by bioassay ( 22 milk samples from eight ewes seropositive; IFA $\geq 256$ ) and PCR [for the detection of agent in the brains of mice inoculated on bioassay and directly from milk (108 samples from 42 seropositive ewes (IFA, $\geq 64$ ) in different lactation periods)]. T. gondii DNA was detected in mice brains inoculated with milk from eight sheep (a sample of the 45th day of lactation and seven in the collection of 90th day) and directly from the milk in samples of the second collection (90 days) in five animals. Taking into account both assays, from a total of 42 ewes in lactation and seropositive for $T$. gondii, 30.95\% (13/42) of the animals presented evidences of $T$. gondii presence in milk. Positive PCR samples were sequenced and the results confirmed $\geq 97 \%$ identity with the membrane antigen P22 gene of $T$. gondii. The results showed that $T$. gondii is present in the milk of sheep, representing a possible source of infection to humans through the consumption of milk "in natura" and/or derivatives, besides the possibility of lactogenic transmission to lambs.
\end{abstract}

Keywords: Toxoplasma gondii, milk sheep, PCR, Santa Catarina state

\section{RESUMO}

O objetivo deste estudo foi detectar Toxoplasma gondii no leite de ovinos leiteiros na mesorregião oeste de Santa Catarina, por meio do bioensaio (22 amostras de leite de oito ovelhas soropositivas para $\mathrm{T}$. gondii - RIFI 2256) e PCR [nos cérebros de camundongos inoculados no bioensaio e diretamente do leite (108 amostras de 42 ovelhas soropositivas (RIFI $\geq 64)$ em diferentes periodos de lactação)]. DNA de T. gondii foi detectado no cérebro de camundongos inoculados com leite das oito ovelhas (uma amostra do dia 45 e sete do dia 90 de lactação) e diretamente do leite em amostras da segunda coleta (90 dias de lactação), em cinco animais. Considerando os resultados de ambos os ensaios, de 42 ovelhas em lactação e soropositivas para T. gondii, 30,95\% (13/42) dos animais apresentaram evidências da presença do parasito no leite. As amostras positivas na PCR foram sequenciadas e os resultados confirmaram $\geq 97 \%$ de identidade com o antígeno de membrana gene P22 de T. gondii. Os resultados mostraram que o T. gondii está presente no leite de ovelhas, o que representa uma possível fonte de infecção para os seres humanos, por meio do consumo de leite in natura elou de derivados, além da possibilidade de transmissão lactogênica aos cordeiros.

Palavras-chave: Toxoplasma gondii, leite ovino, PCR, Santa Catarina

Recebido 20 de outubro de 2016

Aceito em 4 de janeiro de 2017

* Autor para correspondência (corresponding author)

E-mail: anderson.moura@udesc.br 


\section{INTRODUCTION}

Toxoplasma gondii is a protozoan that can infect warm-blooded animals including humans. It is highly prevalent in many areas of the world, and important in human medicine and veterinary (Tenter et al., 2000).

In Brazil, studies have reported wide distribution of sheep toxoplasmosis and occurrence of anti- $T$. gondii antibodies ranging between $7.7 \%$ and 52\% (Silva and Langoni, 2001; Lopes et al. 2010).

Most cases of human toxoplasmosis are attributed to the consumption of raw meat or food and water infected with oocysts. However, Skinner et al. (1990) emphasize that the consumption of contaminated milk can cause serious clinical disorders in immunocompromised children and pregnant women and Tenter et al. (2000) reported seroconversion to $T$. gondii in children taking the goat milk regularly.

The presence of $T$. gondii tachyzoites has been reported in the milk of sheep, goats, cattle and mice (Chiari and Neves, 1984; Vitor et al., 1991; Remington et al., 2004, Ragozo et al., 2009; Camossi et al., 2011).

Since clinical toxoplasmosis in humans associated with unpasteurized goat milk consumption has already been registered (Chiari and Neves, 1984), the biological similarities between species to suggest that sheep milk is also considered a potential source for human infection, making it important to research $T$. gondii in this fluid.

\section{MATERIAL AND METHODS}

For the study, 108 samples of milk (42, 37 and 29 samples at 45, 90 and 120 days of lactation, respectively) were collected from 42 lactating ewes that were seropositive (IFA) to $T$. gondii, with antibody titers of 1:64 (26) 1: 256 (12) 1 1024 (three) and 1: 4096 (one) to research the agent by PCR and bioassay. The samples were from animals of a farm of dairy sheep, located in Chapecó, West messoregrion of the state of Santa Catarina. In a previous study (unpublished data), sheep in this farm showed occurrence of antibodies against $T$. gondii of $12.4 \%$ (39/298).
The sheep were bred in semi-extensive system, with native pasture diet and supplemented with feed. The average age of lactating ewes was 1.5 years.

IFA for IgG anti- $T$. gondii was performed using RH strain tachyzoites as antigens. Negative and positive control serums were added to each slide and anti-sheep or anti-mice antibody conjugated to fluorescein isothiocyanate that were used. The IFA cut-off value was 1:64 (for sheep and mice) and the positive samples were subjected to fourfold dilutions, until the maximum titration reaction was reached.

The samples (10mL each) were obtained by manually milking the teats and were collected in sterile polypropylene tubes DNAses and RNAses free and kept under refrigeration $\left(4-8^{\circ} \mathrm{C}\right)$ until arrival at the Laboratório de Parasitologia e Doenças Parasitárias do Centro de Ciências Agroveterinárias (CAV) da Universidade do Estado de Santa Catarina (UDESC) in Lages, SC. Two aliquots $(3 \mathrm{~mL})$ of milk were extracted and stored at $-20 \mathrm{C}^{\circ}$ for PCR. The remaining sample was used for the bioassay.

For PCR, $4 \mu \mathrm{L}$ of extracted DNA (quantified using the Nanodrop ${ }^{\circledR}$ kit according to the manufacturer's instructions) from milk samples $(250 \mu \mathrm{L})$ was added to $21 \mu \mathrm{L}$ of a mixture of 3.0 $\mathrm{mM}$ of each primer, $1.0 \mathrm{mM}$ dNTPs, $1.0 \mathrm{mM}$ $\mathrm{MgCl} 2$ and $0,2 \mathrm{U}$ of Taq DNA polymerase. Amplification of parasite DNA was performed in a thermocycler: Five minutes at $94^{\circ} \mathrm{C}$ for denaturation in a single cycle, followed by 35 cycles of one minute at $94^{\circ} \mathrm{C}$ for denaturation, one minute at $60^{\circ} \mathrm{C}$ for annealing and one minute at $72^{\circ} \mathrm{C}$ for extension, followed by a final extension of seven minutes at $72^{\circ} \mathrm{C}$. The PCR products were subjected to agarose gel electrophoresis $2 \%$ stained with "red gel". DNA of the T. gondii VEG strain were used as positive control, and ultrapure water as negative control (Moura et al., 2011). The SAG2R4 (59GCATCAACAGTCTTCGTTGC39) and SAG2F4

(59GCTACCTCGAACAGGAACAC39) primers were used to amplify a DNA segment of $332 \mathrm{Kd}$.

Of the 108 samples of milk obtained, 23 from eight lactating ewes (Table 1) were selected because they had higher titers of antibody [1: 256 
(six), 1: 1024 (one) and 1: 4096 (one)] and were used in the bioassay.

For bioassay Swiss albino mice were used, of both sexes over the age of two months from the vivarium of the Universidade do Estado de Santa Catarina (UDESC) (CAV/UDESC). Milk samples $(7 \mathrm{~mL})$ were centrifuged at $2.500 \mathrm{rpm}$ for 10 minutes. The supernatant was discarded and to the sediment antibiotic was added [Benzylpenicillin benzathine 3.000,000UI, Benzylpenicillin procaine $1.500 .000 \mathrm{UI}$, Benzylpenicillin Potassium 1500.000UI, Dihydrostreptomycin base (sulfate) $1.250 \mathrm{mg}$ and Streptomycin base (sulfate) $1.250 \mathrm{mg}$ ] at a dose of $0.5 \mathrm{~mL} / 2 \mathrm{~mL}$ sample. Following brief manual homogenization, each sample was divided into two equal portions (approximately $1.0 \mathrm{~mL}$ ) and inoculated intraperitoneally in two animals, which were identified and maintained in suitable boxes, with water and food "ad libitum". The inoculated mice were observed daily for the verification of clinical signs of acute infection. After eight weeks, the animals were euthanized (according to principles of animal welfare) for blood and brain collection for serology (IFA) and search for the parasite (by Squash technique and PCR), respectively.

From PCR positive samples (milk and brain), the DNA was purified and ligated into pGem Easy Vector ${ }^{\circledR}$ following the manufacturer's specifications. Briefly, $1 \mu \mathrm{L}$ were added pGEM, $1 \mu \mathrm{L}$ of $\mathrm{T} 4$ DNA ligase, $7 \mu \mathrm{L}$ of purified PCR product and $1 \mu \mathrm{L}$ of ultrapure water. These were ligated for 16 hours at $16^{\circ} \mathrm{C}$ and subsequently transformed into competent $\mathrm{DH} 10 \mathrm{~B}$ calcium. The colonies were screened directly by PCR and the positives were grown in LB liquid medium and then the plasmid DNA was extracted for sequencing

The sequencing of the samples was performed in High Performance Technology Center Laboratory in Life Sciences (LacTad) of the State University of Campinas (UNICAMP), Campinas / SP, using the automatic sequencer ABI 3730XL (Genetic Analyze). The mold 250ng DNA was labeled using $\mathrm{T} 7$ promoter primer 2,5pmol AAT ACG ACT CAC TAT AGG and $3 \mathrm{~mL}$ BigDye Terminator v3.1 reagent (Applied Biosystems) in a final volume of $10 \mathrm{~mL}$. The labeling reactions were performed in a thermocycler with an initial denaturation step at $96^{\circ} \mathrm{C}$ for $3 \mathrm{~min}$, followed by 25 cycles of $96^{\circ} \mathrm{C}$ for $10 \mathrm{sec}, 55^{\circ} \mathrm{C}$ for $5 \mathrm{sec}$ and $60^{\circ} \mathrm{C}$ for $4 \mathrm{~min}$. The precipitated product was diluted in $10 \mathrm{~mL}$ formamide, denatured at $95^{\circ} \mathrm{C}$ for $5 \mathrm{~min}$, cooled on ice for $5 \mathrm{~min}$ and eletroinjetados in automated sequencer. The sequences were analyzed by NucleotidBlast ${ }^{\circledR}$ tool available at http://blast.ncbi.nlm.nih.gov/Blast.cgi?PROGRA $\mathrm{M}=$ blastn\&PAGE TYPE=BlastSearch\&LINK LOC=blasthome, using the parameters "Highly similar sequences (megablast).

This research project was approved by the Ethics Committee for Animal Experimentation of the CAV/UDESC under protocol - 1.03.12

\section{RESULTS AND DISCUSSION}

Considering the results of both techniques, for 42 lactating ewes and positive for $T$. gondii, the parasite DNA was detected in milk of $30.95 \%$ $(13 / 42)$ of the animals and in $12.04 \%(13 / 108)$ of the samples. In no sheep $T$. gondii was detected in more than one milk collection (Table 1).

Directly from milk, the agent was detected in $4.63 \%(5 / 108)$ of the samples, all from the second collection ( 90 days of lactation) in five animals. In the samples of the first and third milk collection no $T$. gondii DNA was detected.

By bioassay, $T$. gondii DNA was detected in the brains of mice inoculated with milk all eight sheep (one in the first sampling, day 45, and seven in the second collection, day 90) (Table 1).

The PCR was used to search the agent in milk, because it is a good indicator of parasite presence in the analyzed material (Mancianti et al., 2013). Although the presence of DNA of the parasite does not indicate the viability of the agent nor its potential infectivity, Moura et al. (2007) observed that PCR have advantages over traditional methods (bioassay) and research shows a good correlation between PCR and bioassay (Homan et al., 2000; Dehkordi et al, 2013.).

All samples have from $97-100 \%$ identity with the membrane antigen $\mathrm{P} 22$ gene of $T$. gondii (GenBank: AB667972.1). 
Toxoplasma gondii in milk...

Table 1. Detection of Toxoplasma gondii (bioassay and PCR) in milk samples from sheep, the West mesorregion of Santa Catarina State, collected at 45, 90 and 120 days of lactation (collections 1,2 and 3)

\begin{tabular}{|c|c|c|c|c|c|c|c|}
\hline \multirow[b]{2}{*}{ Ewe } & \multirow[b]{2}{*}{ IFA } & \multicolumn{3}{|c|}{ BIOASSAY } & \multicolumn{3}{|c|}{ PCR MILK } \\
\hline & & $\begin{array}{l}\text { Collect } 1 \\
\mathrm{n} / \mathrm{S} / \text { PCRc }\end{array}$ & $\begin{array}{r}\text { Collect } 2 \\
\text { n/S/PCRc }\end{array}$ & $\begin{array}{l}\text { Collect } 3 \\
\text { n/S/PCRc }\end{array}$ & Collect 1 & Collect 2 & Collect 3 \\
\hline 2 & $1: 256$ & $2 /-/+$ & $2 /-/-$ & $2 /-/-$ & - & - & - \\
\hline 3 & $1: 1024$ & $2 /-/-$ & $2^{1 /-} /+$ & $2 /-/-$ & - & - & - \\
\hline 42 & $1: 256$ & NR & NR & NR & - & + & - \\
\hline 5 & $1: 64$ & NR & NR & NR & - & - & - \\
\hline 6 & $1: 64$ & NR & NR & NR & - & NR & NR \\
\hline 7 & $1: 64$ & NR & NR & NR & - & - & - \\
\hline 8 & $1: 64$ & NR & NR & NR & - & - & - \\
\hline 110 & $1: 64$ & NR & NR & NR & - & + & - \\
\hline 10 & $1: 64$ & NR & NR & NR & - & NR & NR \\
\hline 11 & $1: 256$ & $2^{1 / 0} /-$ & $2 / 0 /+$ & $2 / 0 /-$ & - & - & - \\
\hline 13 & $1: 256$ & $2 / 0 /-$ & $2 / 0 /+$ & $2^{1 / 0 /-}$ & - & - & - \\
\hline 14 & $1: 256$ & NR & NR & NR & - & - & - \\
\hline 17 & $1: 64$ & NR & NR & NR & - & - & - \\
\hline 19 & $1: 64$ & NR & NR & NR & - & - & - \\
\hline 39 & $1: 1024$ & NR & NR & NR & - & + & - \\
\hline 23 & $1: 256$ & NR & NR & NR & - & - & - \\
\hline 24 & 1:4096 & $2 / 0 /-$ & $2^{1 / 0} /+$ & NR & - & - & NR \\
\hline 28 & $1: 256$ & $2 / 0 /-$ & $2 / 0 /+$ & $2 / 0 /-$ & - & - & - \\
\hline 31 & $1: 256$ & NR & NR & NR & - & - & - \\
\hline 32 & $1: 64$ & NR & NR & NR & - & NR & NR \\
\hline 102 & $1: 64$ & NR & NR & NR & - & - & - \\
\hline 91 & $1: 64$ & NR & NR & NR & - & - & - \\
\hline 131 & $1: 256$ & $2 / 0 /-$ & $2^{1 / 0} /+^{*}$ & $2 / 0 /-$ & - & - & - \\
\hline 61 & $1: 1024$ & NR & NR & NR & - & - & - \\
\hline 86 & 1:64 & NR & NR & NR & - & + & - \\
\hline 67 & $1: 64$ & NR & NR & NR & - & - & - \\
\hline 54 & $1: 64$ & NR & NR & NR & - & - & - \\
\hline 52 & $1: 64$ & NR & NR & NR & - & NR & NR \\
\hline 79 & $1: 64$ & NR & NR & NR & - & - & - \\
\hline 99 & $1: 64$ & NR & NR & NR & - & - & - \\
\hline 45 & $1: 64$ & NR & NR & NR & - & NR & NR \\
\hline 147 & $1: 64$ & NR & NR & NR & - & - & - \\
\hline 56 & $1: 256$ & $2 / 0 /-$ & $2 / 0 /+$ & $2^{1 / 0 /-}$ & - & - & - \\
\hline 102 & $1: 256$ & NR & NR & NR & - & - & NR \\
\hline 120 & $1: 64$ & NR & NR & NR & - & NR & NR \\
\hline 136 & $1: 64$ & NR & NR & NR & - & - & - \\
\hline 150 & $1: 64$ & NR & NR & NR & - & NR & NR \\
\hline 149 & $1: 64$ & NR & NR & NR & - & - & - \\
\hline 129 & $1: 64$ & NR & NR & NR & - & - & - \\
\hline 78 & $1: 64$ & NR & NR & NR & - & + & - \\
\hline 124 & $1: 64$ & NR & NR & NR & - & - & - \\
\hline 133 & $1: 64$ & NR & NR & NR & - & NR & NR \\
\hline
\end{tabular}

$\mathrm{n}$ : Number of mice inoculated in the bioassay

S: $+/-=$ Search result brain cysts through the technique of "Squash"

PCRc: $+/-=$ PCR result of the brains of mice inoculated with milk (* = two mice with positive brain PCR).

${ }^{1}$ : mouse died during the bioassay.

$\mathrm{NR}=$ not done 
Of the 42 lactating ewes, $30.95 \%$ (13/42) showed evidence of the presence of parasite in milk. Higher rate results to those observed by Camossi et al. (2011), in São Paulo, e Santana Rocha et al. (2015), in Bahia, which identified 25\% (5/20) and $6.5 \%(18 / 275)$, respectively, of the sheep excreting $T$. gondii by milk.

In $12.04 \%(13 / 108)$ of samples from milk sheep, in this study, $T$. gondii DNA was detected. Similar results to those obtained by Camossi et al. (2011), in São Paulo, and Moura et al. (2011), in Bahia, which reported $10 \%(7 / 70)$ and $10.5 \%$ $(21 / 200)$ of milk samples from sheep with the presence of the parasite. Also similar results, but in goats, were reported by Mancianti et al. (2013) that detected DNA of $T$. gondii (PCR) in $13 \%(10 / 77)$ of samples of milk from animals naturally infected in Italy. Lower values were reported in Fusco et al. (2007), in Italy, and Tavassoli et al. (2013), in Iran, they found 3.4\% and $4.6 \%$, respectively, of milk samples from sheep with the presence of $T$. gondii.

Camossi et al. (2011) analyzed, through PCR, 69 milk samples from seronegative sheep and did not find the agent and, therefore, in this study, $T$. gondii was searched only in milk from seropositive sheep. However, Bezerra et al. (2015), in Pernambuco, Brazil, detected T. gondii DNA in 15 milk samples from naturally infected goats, of which only five had antibodies (IFT, $\geq$ 1:64) against the agent.

In none of the inoculated mice was verified the presence of cysts by the methodology of "squash". This result is due probably to the low concentration of tachyzoites in this fluid (milk), insufficient to cause clinical disease in mice and/or induce the formation of cerebral cysts in an amount sufficient to be detected by this technique.

All mice were seronegative for T. gondii (IFAT, $\geq 1$ : 64). This result may reflect the low parasite load found in milk, the virulence of the strain and the individual animal immune response that can generate antibody levels undetectable in the dilution of 1:64. The prozone phenomenon (Richtzenhain and Soares, 2006) can also influence the results obtained in this study. Still, Rosa et al. (2001) and Trevisani (2013) found that mice inoculated, even with cysts on SNC and/or tachyzoites not seroconverted, while others were seropositive (IFA 1:16) without the detection of tissue cysts (Trevisani, 2013). Divergences between results of isolation agent by bioassay and serology of the inoculated mice were also observed by Holsback et al. (2012) and Cademartori et al. (2014).

The presence of the agent in milk may be the effect of physiological changes in the immune system at the time of peripartum, which favor the conversion of bradyzoites in tachyzoites (process which can be caused by various phenomena of immune order, mainly cellular immunity) and thus could reach the milk (Camossi et al., 2011). The papers show that tachyzoite is the evolutionary phase normally present in milk (Dubey and Beattie, 1988) and, although they can be inactivated by the gastric juice, Cook et al. (2000) presented results that indicate that the ingestion of raw milk, and/or their derivatives, can cause human infection. This is possible if they penetrate the oral and/or pharyngeal mucosa before reaching the stomach (Sacks et al., 1982) or a part of tachyzoites excreted in the milk which is not destroyed by the gastric juice due to its rapid passage through this digestive compartment (Tavassoli et al., 2013). Dubey (1998) showed that within two hours tachyzoites resist in solution pepsin and trypsin and cats can acquire the infection by ingestion of large numbers of tachyzoites. Moreover, Walsh et al. (1999) observed that tachyzoites remain viable in goat milk up to seven days at $4^{\circ} \mathrm{C}$, indicating the risk of consumption of "in natura" milk. Also, in cow's milk, artificially infected with cysts (Hiramoto et al., 2001) of T. gondii, the agent remained viable and can be a source of infection for humans. One hypothesis, not evaluated, is that the milk fat may offer some protection to $T$. gondii tachyzoite regarding the action of gastric juice.

Human toxoplasmosis through ingestion of raw goat milk (Skinner et al., 1990) has already been registered (Chiari and Neves, 1984) and, in state of Minas Gerais, Chiari et al. (1987) found a correlation between human infection and the consumption of goat milk. While epidemiologically these accounts have no impact, in terms of human health they are of concern, even when only isolated cases. Furthermore, the similarity between goats and sheep suggest that the same can occur with sheep milk. Still, the contamination of sheep milk with tachyzoites of $T$. gondii should not be 
overlooked, as some homemade cheeses produced from this raw material, are usually eaten fresh and may pose a risk to human health if they are produced from unpasteurized milk (Fusco et al., 2007). The milk production in the studied property is only intended for human consumption "in natura" and its derivatives.

In this study, most of the animals have the infection in the chronic phase, as shown by the results of ewe's serology. These results demonstrate that sheep, even healthy, may excrete the parasite in milk. In Brazil, Camossi et al. (2011) detected DNA of T. gondii in $10 \%$ from milk (7/70) of naturally infected sheep also in the chronic phase of the disease.

In this study, $T$. gondii DNA was observed in milk samples from 13 animals in only one of the three milk collections over the period $(45,90$ and 120 days of lactation) not featuring intermittency. Powell et al. (2001) found (PCR) and/or isolated (Bioassay) T. gondii in milk samples from five out of six cats experimentally infected with cysts of different strains of the parasite, intermittently. These results, according to the authors, could be related to the volume of samples or the sporadic release of the parasite. Still, the presence of $T$. gondii in cat milk over three weeks of lactation may be responsible for the infection of kittens that are born healthy, congenitally infected, but sicken and die. Despite the differences between species, the same might occur with lambs.

\section{CONCLUSION}

Toxoplasma gondii DNA in the milk of naturally infected sheep indicates the presence of the agent, possibly tachyzoites, if feasible, representing a possible source of infection for humans through milk consumption "in natura" and/or derivatives, beyond the possibility of lactogenic transmission for lambs.

\section{ACKNOWLEDGEMENTS}

For Fundação de Amparo à Pesquisa e Inovação do Estado de Santa Catarina (FAPESC) the granting of financial resources through the Public Call 06/2013 - Grant Term 3541/2013 and Coordenação de Aperfeiçoamento de Pessoal de Nível Superior (CAPES).

\section{REFERENCES}

BEZERRA, M.J.G.; KIM, P.C.P.; MORAES, É.P.B.X. et al. Detection of Toxoplasma gondii in the milk of naturally infected goats in the Northeast of Brazil. Transbound. Emerg. Dis., v.62, p.421-424, 2015.

CADEMARTORI, B.G.; SANTOS, L.M.; OLIVEIRA, F.C. et al. Isolation and pathogenicity of Toxoplasma gondii in naturally infected (rustic farm) pigs in southern Brazil. Vet. Parasitol., v.203, p.207211, 2014.

CAMOSSI, L.G.; GRECA-JÚNIOR, H.; CORRÊA, A.P. et al. Detection of Toxoplasma gondii DNA in the milk of naturally infected ewes. Vet. Parasitol., v.177, p.256-261, 2011.

CHIARI, C.A.; LIMA, W.S.; ANTUNES, C.M.F.; LIMA, J.D. Soro-epidemiologia da Toxoplasmose caprina em Minas Gerais, Brasil. Arq. Bras. Med. Vet. Zootec. v.39, p.587-609, 1987.

CHIARI, C.A.; NEVES, D.P. Toxoplasmose humana adquirida através da ingestão de leite de cabra. Mem. Inst. Oswaldo Cruz, v.79, p.337-340, 1984.

COOK, A.J.; GILBERT, R.E.; BUFFOLANO, W. et al. Sources of toxoplasma infection in pregnant women: European multicentre case-control study. $B M J$, v.321, p.142-147, 2000.

DEHKORDI, F.S.; BORUJENI, M.R.; RAHIMI, E.; ABDIZADEH, R. Detection of Toxoplasma gondii in raw caprine, ovine, buffalo, bovine and camel milk using cell cultivation, cat bioassay, capture ELISA, and PCR methods in Iran. Foodborne Pathog. Dis., v.10, p.120-125, 2013.

DUBEY, J.P. Advances in the cycle of Toxoplasma gondii. Int. J. Parasitol., v.28, p.1019-1024, 1998.

DUBEY, J.P.; BEATTIE, C.P. Toxoplasmosis of animals and man. Boca Raton: CRC Press Inc, 1988. 220 p.

FUSCO, G.; RINALDI, L.; GUARINO, A. et al. Toxoplasma gondii in sheep from the Campania region (Italy). Vet. Parasitol., v.149, p.271-274, 2007.

HIRAMOTO, R.M.; MAYRBAURL-BORGES, M.; GALISTEO JR, A.J. et al. Infectivity of cysts of the ME-49 Toxoplasma gondii strain in bovine milk and homemade cheese. Rev. Saúde Pública, v.35, p.113118, 2001.

HOLSBACK, L.; PENA, H.F.J.; RAGOZO A. et al. Serologic and molecular diagnostic and bioassay in mice for detection of Toxoplasma gondii in free ranges chickens from Pantanal of Mato Grosso do Sul. Pesqui. Vet. Bras., v.32, p.721-726, 2012. 
HOMAN, W.L.; VERCAMMEN, M.; BRAEKELEER, J.; VERSCHUEREN, H. Identification of a 200 - to 300 -fold repetitive $529 \mathrm{bp}$ DNA fragment in Toxoplasma gondii, and its use for diagnostic and quantitative PCR. Int. J. Parasitol., v.30, p.69-75, 2000.

LOPES, W.D.; SANTOS, T.R.; SILVA, R.S. et al. Seroprevalence of and risk factors for Toxoplasma gondii in sheep raised in the Jaboticabal microregion, São Paulo State, Brazil. Res. Vet. Sci., v.88, p.104106, 2010.

MANCIANTI, F.; NARDONI, S.; D'ASCENZI C. et al. Seroprevalence, detection of DNA in blood and milk, and genotyping of Toxoplasma gondii in a goat population in Italy. BioMed. Res. Int., v.2013, 6p, 2013.

MOURA, A.B.; COSTA, A.J.; JORDÃO FILHO, S. et al. Toxoplasma gondii in semen of experimentally infected swine. Pesqui. Vet. Bras., v.27, p.430-434, 2007.

MOURA, R.L.S.; CARVALHO, F.S.; O'DWYER, H.N.S. et al. Identificação de Toxoplasma gondii em leite de ovelhas do Sul da Bahia. In: CONGRESSO BRASILEIRO DE MEDICINA VETERINÁRIA, 38., 2011, Florianópolis. Anais... Florianópolis: [s.n.], 2011. (Resumo)

POWELL, C.C.; BREWER, M.; LAPPIN, M.R. Detection of Toxoplasma gondii in the milk of experimentally infected lactating cats. Vet. Parasitol., v.102, p.29-33, 2001.

RAGOZO, A.M.; YAI, L.E.; OLIVEIRA, L.N. et al. Isolation of Toxoplasma gondii from goats from brazil. J. Parasitol., v.95, p.323-326, 2009.

REMINGTON, J.S.; THULLIEZ, P.; MONTOYA, J.G. Recent developments for diagnosisof toxoplasmosis. J. Clin. Microbiol., v.42, p.941-945, 2004 .

RICHTZENHAIN, L.J.; SOARES, R.M. Técnicas sorológicas e de biologia molecular. In: CUBAS, Z.S.; SILVA, J.C.R.; CATÃO-DIAS, J.L. (Orgs.). Tratado de animais selvagens: medicina veterinária. São Paulo: Roca, 2006. p.967-979.

ROSA, C.; KASAI, N.; SOUZA, S.L.P. et al. Comparação das técnicas de imuno-histoquímica e bioensaio em camundongos para pesquisa de Toxoplasma gondii em tecidos de caprinos, experimentalmente inoculados. Arq. Inst. Biol., v.68, p.13-17, 2001.
SACKS, J.J.; ROBERTO, R.R.; BROOKS, N.F. Toxoplasmosis infection associated with raw goat's milk. J. Am. Med. Assoc., v.248, p.1728-1732, 1982.

SANTANA ROCHA, D.; SOUSA MOURA, R.L.; MACIEL, B.M. et al. Detection of Toxoplasma gondii DNA in naturally infected sheep's milk. Genet. Mol. Res., v.14, p.8658-8662, 2015.

SILVA, A.V.; LANGONI, H. The detection of Toxoplasma gondii by comparing cytology, histopathology, bioassay in mice, and the polymerase chain reaction (PCR). Vet. Parasitol., v.97, p.191-198, 2001.

SKINNER, L.J.; TIMPERLEY, A.C.; WIGHTMAN, D. et al. Simultaneous diagnosis of toxoplasmosis in goats and goatowner's family. Scand. J. Infect. Dis., v.22, p.359-361, 1990.

TAVASSOLI, M.; ESMAEILNEJAD, B.; MALEKIFARD, F. et al. Detection of Toxoplasma gondii DNA in sheep and goat milk in Northwest of Iran by PCR-RFLP. Jundishapur J. Microbiol., v.6, p.e8201, 2013.

TENTER, A.M.; HECKEROTH, A.R.; WEISS, L.M. Toxoplasma gondii: from animals to humans. Int. J. Parasitol., v.30, p.1217-1258, 2000.

TREVISANI, N. Genotipagem de isolados de Toxoplasma gondii obtidos de Gallus gallus naturalmente infectados no Estado de Santa Catarina. 2013. 52f. Dissertação (Mestrado em Ciência Animal) - Universidade do Estado de Santa Catarina, Lages. SC.

VITOR, R.W.A.; PINTO, J.B.; CHIARI, C.A. Eliminação de Toxoplasma gondii através de urina, saliva e leite de caprinos experimentalmente infectados. Arq. Bras. Med. Vet. Zootec., v.43, p.147154, 1991.

WALSH, C.P.; HAMMOND, S.E.; ZAJAC, A.M.; LINDSAY, D.S. Survival of Toxoplasma gondii tachyzoites in goat milk: potential source of human toxoplasmosis. J. Eukaryot. Microbiol., v.46, p.73S74S, 1999. 